\title{
Hogyan fejlesszük egy ország egészségkultúráját? A RAND Corporation jelentésének ismertetése
}

\author{
Building a National Culture of Health \\ Review of the RAND Corporation report
}

Szerzők: Kaposvári Csilla $₫$, Vitrai József ${ }^{b}$

a: Pécsi Tudományegyetem Egészségtudományi Doktori Iskola, b: Emberi Erőforrások Minisztériuma

Beküldve: 2017. 09. 14.

doi: 10.24365/ef.v58i3.179

Kulcsszavak: egészségkultúra; egészség és jóllét; közösségi egészségkapacitás; cselekvési keretrendszer

Keywords: culture of health; health and well-being; community health capacity; action framework

\section{BEVEZETÉS}

A Robert Wood Johnson Alapítvány 2013 óta foglalkozik az egészségkultúra-koncepciójának (Culture of Health) kidolgozásával az Egyesült Államokban. A jelen szakirodalmi ismertető tárgya a RAND Corporation által az alapítvány felkérésére készített jelentés. ${ }^{1} \mathrm{~A}$ jelentés 221 oldalban mutatja be a tíz alapelvre épülő (részletesen lásd lejjebb!) egészségkultúra-koncepció megvalósításának cselekvési keretrendszerét, a mérési stratégiát és a megvalósítás kezdeti lépéseit. ' A jelentés hosszú, egy éven keresztül tartó munkafolyamat eredménye, amely szakirodalmi áttekintésen, strukturált szakértői egyeztetéseken és érdekcsoportok bevonásán alapult. A folyamat három fő elemzési szakaszra épült. Az első szakaszban az egészségkultúra tíz alapelvét csoportosították a cselekvési területek azonosítása céljából, majd fiktív logikai modellek segítségével elemezték a lehetséges hatásokat és ellenőrizék, hogy a cselekvési területek megválasztása összhangban van-e a rendelkezésre álló bizonyítékokkal (például eredmények és kimenetek, amelyek bizonyítékokhoz kapcsolódnak). Végül a koncepció feltérképezése következett az érdekcsoportok széles körében, amivel ellenőrizték, hogy a cselekvési területekre vonatkozó fogalmi csoportosítások érthetők és alkalmazhatók voltak a különféle érdekcsoportok által. A mérési stratégia kidolgozását követően a szakirodalmi áttekintés és szakértői csoportelemzések során a cselekvési területek lényegi elemeit leginkább megragadó indikátorok azonosítása és szelekciója történt meg.

\section{HOZTA LÉTRE EZT AZ EGÉSZSÉGKULTÚRÁVAL KAPCSOLATOS KEZDEMÉNYEZÉST?}

Az Amerikai Egyesült Államok többet költ egészségügyi ellátásra, mint bármely más ország, ám az amerikai emberek adódollárjai nem hozzák meg az elvárt hatást a lakosság egészségi állapotában. Az amerikaiak születéskor várható élettartama a negyven legfejlettebb ország közül csak a 26. 
Egyre nyilvánvalóbbá vált, hogy az amerikai emberek egészségi állapotának javításához az egészségügyi rendszer megreformálásán kívül többre van szükség. A szerzők kiemelik, hogy az egészség több társadalmi rendszer múködésének eredménye, nem kizárólag az egészségügyi ellátásoké. Az egészség-magatartásnak, a társadalmi és fizikai környezetnek - ahol az emberek élnek és dolgoznak -, erősebb hatása van a jóllétre, mint kizárólag az egészségügyi szolgáltatásoknak. Ezért az összes szektor egészségben betöltött szerepének és cselekvési lehetőségeinek újragondolása szükséges. Ez olyan átalakulást foglal magában, ahol az egészségügyi rendszer az egészség, a népegészségügy és a szociális ellátórendszer közötti egyensúlyt teremtő szerepet tölt be annak érdekében, hogy az egyéneknek és a közösségnek a legmagasabb szintû értéket hozza létre.

A szerzők megállapítják, hogy az egészség tágabb értelmezését továbbá olyan nagyobb társadalmi változások is szükségessé teszik, mint például a lakosság elöregedése, a bevándorlás felerősödése. A jóllét és az egészség fejlesztése, a betegségek megelőzése olyan különböző szervezetek programjaiba is bekerült, amelyek tradicionálisan nem foglalkoztak az egészség kérdésével. Ezek a változások felerősítették az USA-ban azt a nemzeti mozgalmat, amely kiköveteli és támogatja a széles körben elfogadott és komplex egészségkultúra jövőképét.

A jelentésben a kultúrát úgy definiálják, mint a hiedelmek, attitűdök, értékek és cselekvések megosztása és összehangolása az egyének, a szervezetek szintjén és a döntéseket hozó intézményekben (például ahol a politikák vagy törvények születnek). Nincs egy közös kultúra, inkább a kultúra a különböző földrajzi vagy demográfiai határok által létrehozott közösségekben fejlődik. A jelentés az egészség meghatározásában a $\mathrm{WHO}^{2}$, a Stoto-féle ${ }^{3}$ populációs szintû egészség és jóllét, valamint az Ottawai Karta ${ }^{4}$ által képviselt egészségértelmezést veszi alapul.

A jelentés szerint az egészségkultúra akkor jön létre, amikor az egészséget minden szektor kiemelt értéknek tekinti, és amikor az egyének és szervezetek rendelkeznek azzal a képességgel, hogy az egyéni és közösségi jóllétet előmozdítsák, hogy olyan fizikai és társas közeget teremtsenek, ahol az egészség prioritás, továbbá támogatják, hogy mindenki hozzáférjen az egészséges életmód lehetőségeihez és a magas színvonalú egészségügyi ellátáshoz. Az egészségkultúra tehát nem más, mint annak átformálása, ahogyan a társadalom az egészségről gondolkodik. A folyamat eredményeként kialakult egészségkultúra csak komplex, rendszerszintű változások alapján valósulhat meg.

Az alapítvány az ismertetett folyamat első lépéseként az egészségkultúra tíz alapelvét fogalmazta meg:

1. Optimális egészség és jóllét van minden földrajzi térségben, demográfiai és társadalmi csoportban.

2. Mindenki számára fontos az egészség és az egészség megtartása, ehhez a társadalom minden tagjának megvan a lehetősége.

3. Az egyének és a családok képesek és lehetőségük is van olyan döntéseket hozni, melyek egészséges életmódhoz, optimális jólléthez és funkcionalitáshoz vezetnek.

4. A kormány, az egyének, az üzleti élet szereplői, szervezetek és intézmények együtt dolgoznak az egészséges közösségek és az egészséges életmód támogatásán.

5. Mindenkinek van hozzáférése megfizethető és magas színvonalú egészségügyi ellátáshoz megelőzéshez és gyógyító ellátáshoz egyaránt.

6. Senki sem marad ki a rendszerből.

7. Az egészségügyi ellátórendszer hatékony és méltányos.

8. A gazdaságot nem terhelik túlzott és indokolatlan egészségügyi kiadások.

9. Az emberek egészsége vezérli a magán- és a közszféra döntéseit.

10.Az amerikai emberek megértik, hogy az egészség és jóllét állapotát csak együttesen tudják elérni.

\section{A CSELEKVÉSI KERET KIFEJLESZTÉSE}

A jelentésben bemutatott cselekvési keret célja, hogy holisztikus és integrált rendszerbe foglalja öszsze azokat a lépéseket, amelyek szükségesek a populációs szintû egészség és jóllét eléréséhez. Az egészségkultúra cselekvési keretrendszerének cselekvési és kimeneti területeit az 1.ábra mutatja be. 


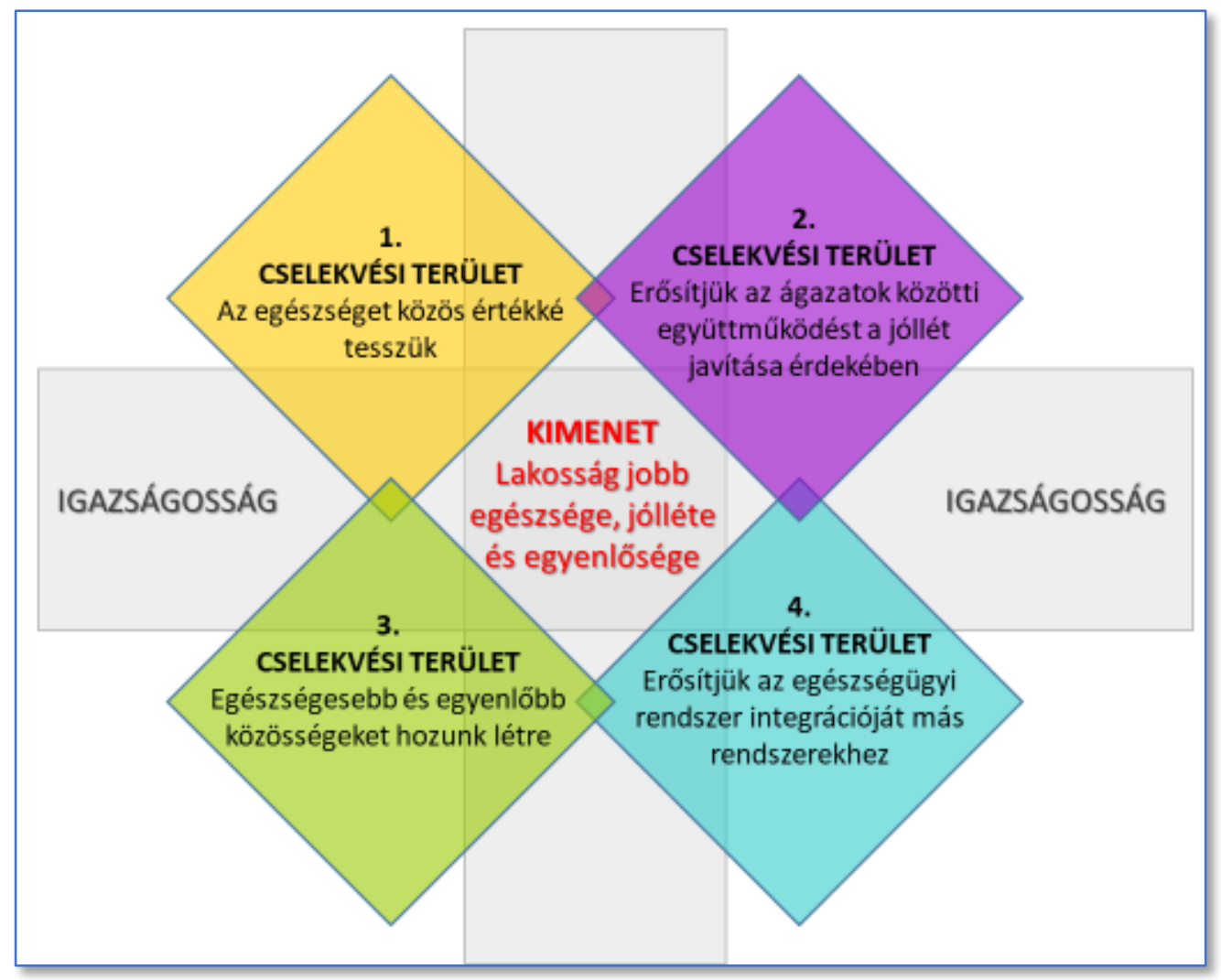

Forrás: A jelentésben szereplő Figure S.1. nyomán saját szerkesztés

Az egészségkultúra cselekvési keretrendszere négy cselekvési területből és egy kimeneti területből áll. A szerzők kiemelik, hogy bár az ábrán nem szerepel, de mindegyik cselekvési területhez tartoznak ún. háttérfolyamatok (driverekii). Ezek a beavatkozási prioritások elengedhetetlenek a lakosság egészségének időben fenntartható javulásához és a cselekvési terület fejlődéséhez egyaránt; ezért ezek időben állandó prioritások, és mihamarabb fel kell gyorsítani bennük a változást az USA-ban.

Minden cselekvési területhez tartoznak még meghatározott indikátorok, amelyek az elörehaladás/fejlődés mérésének kiindulópontjaként és a változási folyamat követésére szolgálnak. A mérési rendszer rugalmas és támogatja, hogy az érintett csoportok párbeszédén alapulva az előrehaladás más kulcsterületei is előtérbe kerüljenek a monitorozás folyamán. Például a könyvtári szolgáltatáshoz való hozzáférés nemcsak a kulturális szektort hozza be a folyamatba, de párbeszédet indíthat el arról, hogy a közösségben milyen jóllétet szolgáló intézkedések, lehetőségek érhetők el.

A négy cselekvési területet a szerzők az alábbiakban foglalják össze:

Az 1. cselekvési terület: az egészséget közös értékké tesszük

E terület fókusza, hogy az egyének között milyen mértékben közös érték az egészség, és milyen mértékű az egymásrautaltság érzése. Közös értéken azt értik, hogy az egyének és a közösségek az egészséget prioritásként kezelik, az egészség vezérli a helyi döntéshozatalt, a közösségek nagy elvárással fordulnak a környezetük, az egészségügyi és szociális rendszer felé. Továbbá az emberek átélik, hogy az egészségük hatással van másokra és viszont. Olyan döntéseket hoznak, amelyek nemcsak a saját egészségüket fejleszti, hanem a közösségük többi tagjáét is. Az egészség közös értékké tétele többszintű

ii Driver: Olyan háttérfolyamat, háttérmechanizmus, amely alapfeltétel a cselekvési terület múködéséhez. 
folyamat, az egyéni szint mellett közösségi/szervezeti szinten is kialakul. Ide értendők a családi kapcsolatok, a szomszédok, a szervezetek közötti interakciók, valamint az egyéni és szervezetek közötti kapcsolatok szintjei is. E terület megértéséhez és fejlesztéséhez a szociális hálózatokkal, a közösségek ellenálló képességével, a jólléttel, a viselkedés közgazdaságtanával valamint a közösségi vagyon fejlesztésével foglalkozó kutatások járulhatnak hozzá. A szerzők három alapvető háttérfolyamatot emelnek ki az egészség mint közös érték kialakításában:

- gondolkodásmód és elvárások,

- közösségtudat,

- civil részvétel.

Az egészség mint közös érték érzése (azaz az egészség olyan prioritás, amelynek értéke van) előfeltétel az egészségkultúra kiépítéséhez. Az egészség mint közös érték kialakításához és megértéséhez szükséges a lakosság érthető tájékoztatása és a megfelelő kommunikáció. A közös érték megteremti az igényt az egészséges közösségek kialakítására, ezáltal beindul az egészségkultúra felé történő változás. Ehhez a változáshoz a gondolkodásmód mellett elengedhetetlen olyan közösségek megléte, amelyek képesek tudatosítani a közös igényt (közösségtudat), képesek magukat mobilizálni és megszervezni (civil részvétel) az egészséges környezetüket.

A gondolkodásmód és elvárások háttérfolyamat az egyének, családok és szervezetek egészségről alkotott elképzeléseit, véleményét és elvárásait jelenti. Ezek megértése segít abban, hogy a közösségi szerveződés és kommunikációs folyamatok mely pontjain lehet beavatkozni az egészség érdekében történő mozgósításhoz. Az erős közösségi érzés megléte is fontos a változásban. Azok a közösségek, ahol erős az összetartozás és hatékony az önszerveződés, jobban felismerik az igényeiket és képesek cselekedni azok mentén. Az összetartozásra épülő közösségekben és ahol bizalom van az egyénekben, folyamatokban és intézményekben, könnyebben alakítható ki az egészségkultúra, könnyebben elsajátíthatók a kulturális értékek, normák és hagyományok. Ezzel összefüggésben a civil részvétel előfeltétele, hogy az egyének érezzék, van hatásuk a változásokra, a civil részvétel viszont elengedhetetlen az egészségre vonatkozó közös igények, tervek és ösztönzők megfogalmazásában. A civil részvételt befolyásoló tényezőket három szinten meghatározva az 1. táblázat foglalja össze.

1. táblázat: A civil részvételt befolyásoló egyéni, közösségi, döntéshozatali tényezők

\begin{tabular}{l|l}
\hline \multicolumn{2}{l}{ Tényezök } \\
\hline Szint & - Érdeklődés a civil részvétel vagy civil érdekképviselet iránt \\
\hline Egyéni & - Annak érzése, hogy a civil szerepvállalás fontos és értékelt \\
\hline - A civil szerepvállalás szervezetek általi támogatása \\
\hline Szervezet/Közösség & - A közösség érdeklődése a döntéshozatalban való civil szerepvállalás iránt \\
\hline - A közösségi vagyon ismerete
\end{tabular}

Forrás: A jelentés 5.3 táblázata nyomán ${ }^{1}$

A fenti háttérfolyamatok tekintetében a szerzők az alábbi mérési területeket és illusztratív indikátorokat határozták meg:

- az egymásrautaltság érzésének mértéke az egészség területén,

- a jóllét értéke,

- egészségfejlesztéssel és jólléttel kapcsolatos közviták száma,
- közösségtudat,

- szociális támogatottság,

- szavazati részvétel,

- önkéntesség.

Az elvégzett munka és a cselekvési keretrendszer kidolgozottságára példaként álljon itt a jelentés 1 . cselekvési területéhez tartozó háttérfolyamat/indikátor/hozzájárulás táblázata (2. táblázat) 
2. táblázat: Háttérfolyamatok szerinti mutatók: Az egészséget közös értékké tesszük ${ }^{1}$

Háttérfolyamat

Mutató
Mit mér a cselekvési területen/ a teljes egészségkultúrában?

\begin{tabular}{|c|c|c|}
\hline $\begin{array}{l}\text { Gondolkodásmód és } \\
\text { elvárások }\end{array}$ & $\begin{array}{l}\text { A Twitteren az egészségfejlesztés és jóllétről } \\
\text { szóló bejegyzések és az akut orvosi ellátásról } \\
\text { szóló bejegyzések egymáshoz viszonyított } \\
\text { aránya. }\end{array}$ & $\begin{array}{l}\text { A betegségek kezelésén túl megmutatja az } \\
\text { egészségfejlesztéssel kapcsolatos fogyasztói } \\
\text { magatartás és érzelmek megváltozását. }\end{array}$ \\
\hline $\begin{array}{l}\text { Gondolkodásmód és } \\
\text { elvárások }\end{array}$ & $\begin{array}{l}\text { Azoknak a felnőtteknek az aránya, akik } \\
\text { egyetértenek azzal, hogy az egészségüket } \\
\text { jelentősen befolyásolják a társaik, a } \\
\text { szomszédaik és a tágabb közösségük. }\end{array}$ & $\begin{array}{l}\text { Azt jelzi, hogy milyen mértékben értik meg az } \\
\text { emberek, hogy az egészség függ egymástól, és az } \\
\text { egyéni viselkedés befolyásolja a közösség jóllétét és } \\
\text { fordítva. }\end{array}$ \\
\hline $\begin{array}{l}\text { Gondolkodásmód és } \\
\text { elvárások }\end{array}$ & $\begin{array}{l}\text { Azoknak a felnőtteknek az aránya, akiket } \\
\text { érdekel, mit tesz a közösségük a jóllétért. }\end{array}$ & $\begin{array}{l}\text { Betekintést ad abba, hogy az egyéneket mennyire } \\
\text { érdekli és mennyire prioritásuk az egészségkultúra, } \\
\text { illetve tágabban mennyire elvárás a jóllét. }\end{array}$ \\
\hline Közösség érzése & $\begin{array}{l}\text { A Közösség Érzése Index két alskálájának } \\
\text { összesített értéke: érzelmi kapcsolat (a } \\
\text { közösséggel), és tagság (a közösséghez } \\
\text { tartozás érzése). }\end{array}$ & $\begin{array}{l}\text { A kohézió relatív érzését jelenti, amely alapvető az } \\
\text { egészségkultúra fejlesztésében, az elköteleződés és } \\
\text { a közös értékek érzésében. }\end{array}$ \\
\hline Közösség érzése & $\begin{array}{l}\text { Azoknak a felnőtteknek az aránya, akik } \\
\text { megfelelő társas támogatottságot éreznek a } \\
\text { társuktól, a családjuktól és a barátaiktól. }\end{array}$ & $\begin{array}{l}\text { Két dolgot jelöl: az egészségre és jóllétre vonatkozó } \\
\text { kapcsolódás érzését, valamint azt, hogy a közösség } \\
\text { tagjai milyen mértékben nyújtanak támogató és } \\
\text { egészséges környezetet. }\end{array}$ \\
\hline Civil részvétel & $\begin{array}{l}\text { Választások során a szavazatra jogosult } \\
\text { voksoló polgárok aránya. }\end{array}$ & $\begin{array}{l}\text { A civil részvétel egyik indikátora, amely egyben } \\
\text { kulcsindikátora az egészségkultúra fejlődésének, } \\
\text { jelzi mennyire képesek a közösség tagjai az } \\
\text { egészségért és a jóllétért tenni. }\end{array}$ \\
\hline Civil részvétel & $\begin{array}{l}\text { Önkéntességről beszámoló felnőttek és } \\
\text { fiatalok aránya. }\end{array}$ & $\begin{array}{l}\text { Egyrészt a civil részvétel egyik indikátora, másrészt } \\
\text { jelzi a közösség érdekében tett altruista } \\
\text { cselekedetek mértékét, amely kulcsfontosságú az } \\
\text { egészségkultúrában. }\end{array}$ \\
\hline
\end{tabular}

Forrás: A jelentés 5.4 táblázata nyomán ${ }^{1}$

\section{A 2. cselekvési terület: erősítjük az ágazatok közötti együttmúködést a jóllét javítása érdekében}

Az ágazatok közötti együttmúködések célja, hogy összekapcsolja a hagyományosan egészségfókuszú szektorok (népegészségügy, egészségügyi, szociális ellátórendszer) tevékenységét olyan szektorokkal, amelyek hozzájárulása az egészséghez és a jólléthez az utóbbi években került az érdeklődés központjába (üzleti szektor, oktatás, lakhatás, jog, közlekedés, városfejlesztés stb.). Az ágazatok közötti együttmúködések terén három kritikus háttérfolyamatot azonosítanak: az együttmúködések száma és minősége, beruházások az ágazatokon belül, valamint az együttmúködéseket támogató politikák.

Ez azt is jelenti, hogy az ágazatok tisztában vannak a szerepükkel és az egészséghez való hozzájárulásukkal, hatékonyan múködnek együtt és megvannak a folyamatos együttmúködéshez szükséges források és szabályozások.

Ehhez a cselekvési területhez az alábbi mérési területeket azonosították:

- a helyi egészségügyi igazgatás együttmúködései,

- az iskolai egészségfejlesztés lehetőségei,

- munkahelyi egészségfejlesztés és az egészségkultúra támogatása a vállalatoknál,

- vállalati adományozás,

- szövetségi szintű egészségfejlesztési célú allokáció a táplálkozás és a benti és kültéri fizikai aktivitás terén,

- közösségi kapcsolatok és támogató szabályozás,

- egészséges és egészségtelen termékek, üdítőitalok reklámjának való kitettség a fiatalok körében,

- klímaváltozásnak való kitettség és adaptáció,

- egészséges közpolitikák (például dolgozó családok támogatása). 
A 3. cselekvési terület: egészségesebb és egyenlőbb közösségeket hozunk létre

Ennek a cselekvési területnek a célja az, hogy a fizikai, szociális és gazdasági környezet - amelyben az emberek élnek, dolgoznak és pihennek - biztosítsa, hogy az egészséges választás legyen a legkönnyebb alternatíva mindenki számára, beleértve a hátrányos helyzetű társadalmi csoportokat is, úgymint az etnikai csoportokat, a szegényebb területen élőket, mivel számukra bizonyítottan korlátozottan kínálnak egészséges lehetőségeket. A szerzők kiemelik a rossz egészségi állapot kialakulásában a strukturális háttérfolyamatok szerepét, ezek közül is az etnikai alapú területi szegregációt, mint a társadalmi-gazdasági forrásokhoz, az iskolákhoz a kiskereskedelmi egységek szolgáltatásaihoz, és egyéb egészségfejlesztő tevékenységekhez való hozzáférés legfontosabb meghatározó tényezőjét.

Három alapvető háttérfolyamatot azonosít a jelentés az egészségesebb és egyenlőbb közösségek kialakításában: az épített és fizikai környezet állapota, a szociális és gazdasági környezet, szabályozás és kormányzás.

Ehhez a cselekvési területhez az alábbi mérési területeket azonosították:

- a lakhatás megfizethetősége,

- egészséges élelmiszerhez való hozzáférés,

- a fiatalok biztonsága,

- lakóhelyi szegregáció,

- kora gyermekkori fejlesztés,

- közkönyvtárak,

- átfogó közterület-szabályozás,

- levegőminőség.

4. cselekvési terület: erősítjük az egészségügyi rendszer integrációját más rendszerekhez

E cselekvési terület víziója egy koordinált, átfogó egészségügyi rendszer, amely egyensúlyt teremt és integrálja az egészségügyi ellátórendszert, a népegészségügyet, a szociális ellátást és rendszert. A jövő egészségügyi rendszere egyén- és családközpontú, bizonyíték- és értékelésalapú, valamint együttmúködő csoportokra épülő lenne. Célja, hogy javítsa a lakosság egészségi állapotát és jóllétét, minimálisra csökkentse az ápolási terheket, és növelje a családok és egyéb segítők ápolási kapacitásait. Egymással összefüggő orvosi, szociális, fejlesztési, viselkedéses és oktatási igényeket elégítene ki az optimális egészség és jóllét érdekében olyan élő vagy virtuális egészségcsoportokra alapozva, amelyek együtt dolgoznak a családokkal, orvosokkal, közösségi partnerekkel és más szakemberekkel. A szociális ellátások jelentősége, illetve az integráció jelenlegi hiánya az egészségügyi ellátással, megmagyarázhatja azt a jelenséget, hogy bár az OECD-országok közül az USA-ban költenek legtöbbet az egészségügyi ellátásra, míg relatíve keveset a szociális ellátásra, ott a legrosszabbak az egészségmutatók.

A jelentés három háttérfolyamatot azonosít ezen a területen is: hozzáférés; fogyasztói szemlélet és minőség; egyensúly és integráció. Ez a három tényező kulcsfontosságú a preventív szolgáltatások korai használatában, az egészségügyi kiadások egyensúIyában és a magas színvonalú egészségügyi ellátás elérésében.

Ehhez a cselekvési területhez az alábbi mérési területeket azonosították:

- hozzáférés a népegészségügyi szolgáltatásokhoz,

- hozzáférés az állandó egészségügyi biztosításhoz,

- hozzáférés a mentális egészséggel kapcsolatos szolgáltatásokhoz,

- a fogászati ellátás igénybevétele az előzőévben,

- fogyasztói vélemények,

- az egészségügyi ellátáshoz hozzáférő lakosság aránya,

- az orvosi rekordok elektronikus összekapcsoltsága,

- a védőnők/ápolónők múködésének jogi szabályozottsága,

- szociális kiadások az egészségügyi kiadások arányában.

Kimeneti terület

A tíz alapelvre épülő egészségkultúra három kimeneti területén belül - azaz a lakosság egészségi állapota, a jóllét és az egyenlőség - további három indikátort azonosít a jelentés. Ezek a növekvő egyéni és közösségi jóllét, ellátott krónikus betegségek és csökkenő toxikus stressz, csökkenő egészségügyi kiadások. E kimeneti területen mérhetők a négy cselekvési területen és a hozzájuk tartozó háttérfolya- 
matokban történt változások hatásai. A hagyományos egészségmonitorozási rendszerek, különösen az egyes megbetegedések követésére szorítkozók, nem elégségesek és átfogók a komplex, rendszerszintû változások mérésére.

A kimeneti területhez az alábbi mérési indikátorokat azonosították:

- a jóllét mértéke,

- a gondozók terhei,

- ártalmas gyermekkori tapasztalatok,

- a családok egészségügyi kiadása,

- a megelőzhető kórházi ellátás aránya,

- életvégi egészségügyi kiadások éves szinten.

\section{MEGVALÓSÍTÁS ÉS KÖVETKEZŐ LÉPÉSEK}

A jelentés kiemeli, hogy mivel a bemutatott egészségkultúra-koncepció úttörőnek számít, a mérési területeken bekövetkező változások követésére alkalmas, jelenleg rendelkezésre álló információk köre számos területen hiányos, például egészségfejlesztés, közösségi egészségkapacitások, ágazatok közötti együttmúködések, közös értékek, a jóllét fejlődése. Ezért a mozgalom ún. tesztközösségekben vizsgálja a változásokat, ezzel kiegészíti az egészségkultúra nemzeti monitorozási rendszerét. Ez segít követni és megérteni, hogyan fejlődik az egészségkultúra helyi szinten. A projekt közösségi tesztrendszere 2015-ben kezdődött el és alapvető jelentőségú annak megértésében, hogy hogyan fejlődnek a közösségek, milyen adatokat használnak a fejlődés követésére, és ezeket hogyan lehet gyűjteni és elemezni annak fényében, ahogy a nemzeti mozgalom előrehalad. Továbbá segítenek megérteni a kulturális változások folyamatát, az esetleges ellenállásokat és akadályokat, ágazatok közötti együttmúködéseket. Rávilágítanak továbbá az olyan egyéni és közösségi erőfeszítésekre is, amely annak a környezetnek a megváltoztatására irányulnak, amelyben az egészségpolitikai döntések születnek és az egészséges élet feltételei megteremtődnek. A fő cél olyan háttérfolyamatok és mutatók azonosítása, amelyekkel mérni lehet a közösségek fejlődését az egészségkultúra elérésében. A mozgalomról, valamint a tesztközösségekről további információt a www.cultureofhealth.org honlapon lehet elérni.

A mozgalom tervezett lépései között szerepel a mérés fejlesztése és a cselekvési keretrendszer mérési stratégiájának kidolgozása, amelynek során megfogalmazzák a mutatók tesztelésére és validálására vonatkozó ajánlásokat is, például hogyan lehet alkalmazni az egyes mérőszámokat helyi vagy országos szinten, és hogyan lehet kommunikálni őket a szélesebb lakosság felé (például fő célcsoportok, kulcsüzenetek). A mérési stratégiának a megvalósítást támogató strukturális változókat is tartalmaznia kell, valamint az egyes ágazatok szerepéhez és bevonódásához kapcsolható faktorokat, a kormányzási struktúrára és a helyi folyamatokra, valamint a helyi és nemzeti felelősségekre vonatkozó információkat is.

A projekt következő fázisában a tesztközösségektől és a nemzeti egészségkultúra monitorozási rendszeréből származó információk felülvizsgálatát és a mérési rendszer finomítását tervezik. Ez azért is fontos, mert a mutatók nemcsak reaktívan mutatják a változást, hanem a meghatározásuk és terjesztésük egyben támogatja, katalizálja és bevonja a közösségeket az egészségkultúra fejlesztésének folyamatába. Az indikátorokkal és a fejlődéssel kapcsolatos tanulási folyamat éves ciklusokban zajlik, amelynek során nemcsak arról kapnak információt, hogy hogyan használják a közösségek a mutatókat, hanem arról is, hogy a kontextus hogyan határozza meg a fejlődést. 


\section{HIVATKOZÁSOK}

${ }^{1}$ Chandra A, Acosta JD, Carman KG, et al. Building a National Culture of Health: Background, Action Framework, Measures, and Next Steps. Santa Monica, CA: RAND Corporation, 2016.

${ }^{2}$ World Health Organization. Constitution of the World Health Organization. Paper presented at the International Health Conference, New York, 1948.

${ }^{3}$ Stoto MA. Community health needs assessments: An opportunity to bring public health and the healthcare delivery system together to improve population health. Improving Population Health. 2013

http://www.improvingpopulationhealth.org/blog/2013/04/community-health-needs-assessments-an-opportunity-tobring-public-health-and-thehealthcare-delivery.html Elérve: 2017. 09. 21.

${ }^{4}$ Az Ottawai Egészségfejlesztési Charta Nemzetközi Egészségfejlesztési Konferencia. In: Kishegyi J, Makara P. (szerk.) Az egészségfejlesztés alapelvei. Az egészségfejlesztés alapvető nemzetközi dokumentumai. Országos Egészségfejlesztési Intézet, 2004 http://regi.oefi.hu/alapdok.htm Elérve: 2017. 09. 11. 